\title{
三軸圧縮下の不飽和砂の進行的なせん断帯発達 過程における間隙水の微視的特性
}

\author{
木戸 隆之祐 1 肥後 陽介 ${ }^{2}$ 高村 福志 ${ }^{3}$ \\ 1学生会員 京都大学 大学院工学研究科社会基盤工学専攻（†615-8540 京都市西京区京都大学桂） \\ E-mail: kido.ryuunosuke.87n@st.kyoto-u.ac.jp \\ 2正会員 京都大学准教授 大学院工学研究科都市社会工学専攻（ $=615-8540$ 京都市西京区京都大学桂） \\ E-mail: higo.yohsuke.5z@kyoto-u.ac.jp \\ 3学生会員 京都大学 大学院工学研究科都市社会工学専攻（干615-8540 京都市西京区京都大学桂） \\ E-mail: takamura.fukushi.56s@st.kyoto-u.ac.jp
}

不飽和土はメニスカス水に働くサクションにより高い強度・剛性を示すが，ピーク強度後は完全飽和土 や乾燥土に比べて明瞭なせん断帯と顕著なひずみ軟化を伴い脆性的な破壊モードを示す．不飽和土の破壊 メカニズムの解明には，せん断帯発達に伴うサクションの進行的な変化や，メニスカス水の分布が巨視的 な力学挙動に及ぼす影響を把握することが重要である. 本研究では, 不飽和砂の三軸圧縮過程で生じるせ ん断帯を X 線 CT で可視化し, 間隙水の曲率，存在形態を調べる画像解析を行った。 その結果，せん断帯 の発達過程でサクションの変化は極めて小さいことがわかった。また，メニスカス水の数の減少がひずみ 軟化の一因であることを明らかにした．特に，せん断帯内部はメニスカス水の数が少なく，軸差応力への サクションの寄与が小さいことが示唆された。

Key Words: partially saturated sand, shear band, X-ray CT, meniscus water, curvature of pore water

\section{1. はじめに}

土は，土粒子 (固相)・水 (液相)・空気 (気相)から成る 多相混合体である，道路盛土や地下水位以上の自然地盤 など，土木工学の対象となる地盤は間隙が部分的に水で 飽和した不飽和土である場合が少なくない，不飽和土内 部の水と空気の境界にはメニスカスが形成され，大気圧

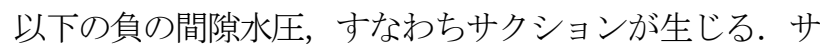
クションは土粒子間結合力を高めるため，不飽和土は完 全飽和土や乾燥土に比べて高い強度・剛性を示す (たと えば 1)-4)). 一方，特に低拘束圧下において，不飽和土 は明瞭なせん断帯と顕著なひずみ軟化を示し脆性的な破 壊モードを示すことが指摘されているらの。このことは 盛土や斜面などの土構造物の破壊と密接に関係しており, 不飽和土のひずみの局所化挙動を明らかにし破壊予測に つなげることが重要である.

不飽和土の力学特性は, 三軸試験や保水性試験などの 実験的研究や構成式，モデル化に関する研究によって, サクション，飽和度，変形性・強度の関係から研究がな されてきた (たとえば 6)-10)). しかしながら，不飽和土 のひずみの局所化メカニズムの解明は完全飽和土や乾燥
土のそれに比べて進んでいない，これは，不飽和土の力 学挙動が三相の微視的な相互作用に依存するが, 微視構 造変化の観察は一般に簡単でない上に，一相あるいは二 相材料に比べて複雑で解明が困難なことが一因である. 土のみの一相系材料のひずみの局所化に関しては，せん

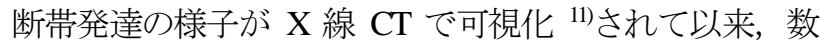
$\mu \mathrm{m}$ レベルの観察が可能なマイクロフォーカス X 線 CT を用いた研究が実施され，局所変形の発生・発達に関す る微視的観点からの知見が得られている ${ }^{12)}$ 。また，三軸 圧縮下の供試体内部における土粒子の運動，変位場・ひ ずみ場を画像解析で明らかにし，破壊メカニズムが定量 的に説明されている ${ }^{13-16) . ~}$

これに対し，著者らの研究グループは，不飽和砂の三 軸圧縮試験にマイクロフォーカス X 線 CT を適用した, 不飽和土のひずみの局所化における微視構造変化の研究 を実施してきた。 CT 画像から土粒子相・水相・空気相 をセグメンテーション (以下，三值化)した結果，せん断 帯内部では間隙比が大きく，飽和度が低い状態になるこ と 10，また，不飽和砂三軸供試体の鉛直方向の飽和度は， 間隙比の分布に依存して不均質に分布することを明らか にした ${ }^{17 .}$. 一方で, せん断帯の発達過程におけるサクシ 
ヨンや間隙水の分布の変化が，不飽和土の巨視的な力学 挙動に及ぼす影響について検証した例はない，具体的に は，ひずみの局所化により密度・飽和度が不均質に変化 する際, 強度・剛性に寄与するサクションの効果がどの ように変化するかは，十分に理解されていない．

本研究の目的は, せん断変形時における不飽和砂の三 相微視構造の変化に着目し, 明瞭なせん断帯と顕著なひ ずみ軟化を伴う破壊メカニズムを明らかにすることであ る. そこで，不飽和土のひずみの局所化による土粒子構 造の変化や, せん断帯の発達過程における間隙水の保水 状態といった微視的特性を明らかにする.

この目的のため, 不飽和砂の三軸圧縮試験中, 所定の 軸ひずみで載荷を中断し, 供試体全体の変形挙動とせん 断帯が発達すると想定される局所領域をマイクロフォー カス X 線 CT で可視化する. 後者の CT 画像は, 土粒子 相・水相・空気相の識別が可能なほど十分高い解像度で 撮影を実施し，三值化によってせん断帯の発達に伴う三 相割合の変化を定量化する. また，三值化画像を用いて 二種類の画像解析を実施する。一つ目は間隙水の存在形 態と数を調べるための Morphology 解析, 二つ目はせん 断変形中のサクション変化を調べるため, 間隙水相を対 象とする曲率解析である. 曲率解析は, 既存の豊浦砂の 水分保持特性試験データを用いて手法の妥当性を検証し ている.これらの CT 撮影および画像解析により，せん 断変形中の間隙水の微視的特性を明らかにする.

\section{2. 試験方法}

\section{（1）試料と供試体作製方法}

これまで著者らの研究グループは, 平均粒径 $\left(D_{50}\right)$ が 約 $200 \mu \mathrm{m}$ の豊浦砂を使用し，CT撮影において一つの土 粒子を 27 Voxel (Voxel の詳細は後述)で表すと, 画像解析 で良好な結果が得られた ${ }^{17}$. 一方, 本研究の実験機構で の Voxel サイズは約 $12 \mu \mathrm{m}$ が限界のため, 画像解析に耐 え得る画像を撮影するためには $324 \mu \mathrm{m}$ 以上の $D_{50}$ の試料 が必要である. そこで本研究では, 目開き $328 \mu \mathrm{m}, 548$ $\mu \mathrm{m}$ のふるいを用いて $D_{50}$ が $324 \mu \mathrm{m}$ 以上になるように粒 度を整えた珪砂 5 号を使用した. 本試料の粒径加積曲線 を図-1 に示寸. 土粒子密度は $2.64 \mathrm{~g} / \mathrm{cm}^{3}$, 最大間隙比は 1.013 , 最小間隙比は $0.694, D 50$ は $456 \mu \mathrm{m}$, 均等係数は 1.3, 細粒分含有率は $0.1 \%$ あるる。

供試体は，モールド内に貯めた脱気水に気乾砂を直接 投入する水中落下法によって作製した. 直径 $35.0 \mathrm{~mm}$, 高さ $70.0 \mathrm{~mm}$ となるよう, 所定量の珪砂 5 号を投入しつ つ，モールドに振動を与えることで密詰めにした，不飽 和状態にする際は, 図-2のような水頭型吸引法 18)により, 供試体上端と二重管ビュレット内の水面に $20.0 \mathrm{~cm}$ の水

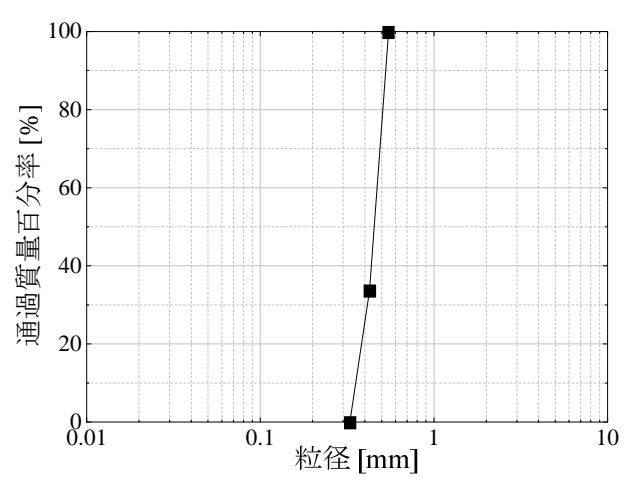

図-1 珪砂 5 号の粒径加積曲線

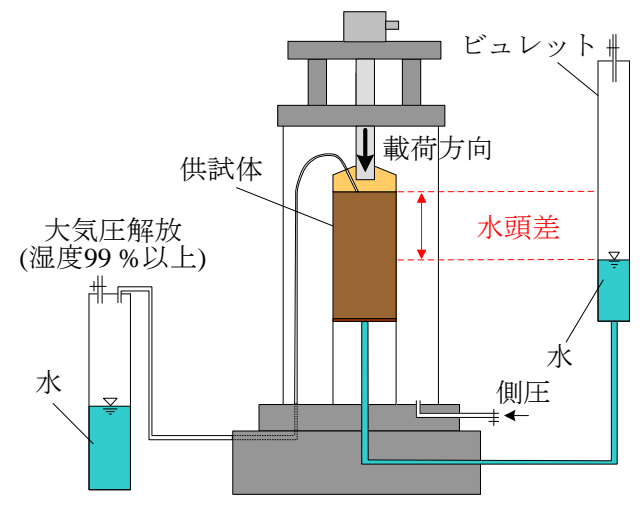

図-2 水頭型吸引法の機構図 ${ }^{18)}$

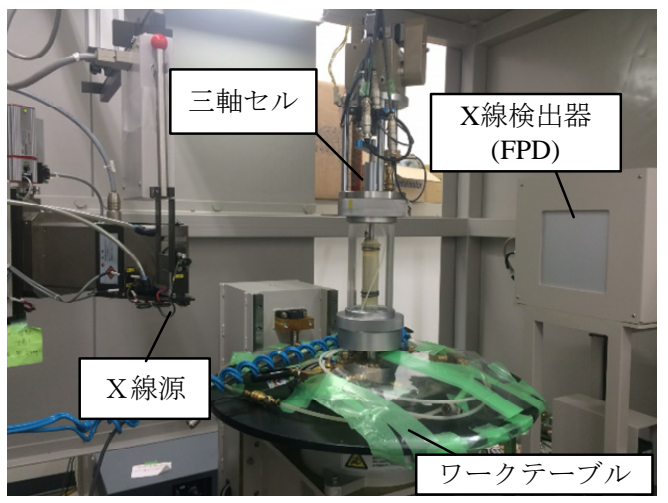

写真-1 マイクロフォーカス X $\mathrm{X}^{\text {線 } \mathrm{CT}^{16}}$

頭差をつけて排水させた．排水した水は二重管ビュレッ 卜に流れ込み, 差圧計によって測定した排水後の平衡時 における供試体上端と二重管ビュレット内の水面との水 頭差は $10.0 \mathrm{~cm}$ となった. この水頭差により, 供試体上 端および下端に作用するサクションはそれぞれ $0.98 \mathrm{kPa}$, $0.29 \mathrm{kPa}$ となった。供試体の相対密度は $90.6 \%$, 間隙比 は 0.724 であり, 排水平衡時の飽和度は $54.6 \%$, 含水比 は $15.0 \%$ となった。

\section{（2）三軸圧縮試験方法とマイクロフォーカス X 線 CT} 本研究のマイクロフォーカス X 線 CT 装置 ${ }^{16}$ (KYOTO-

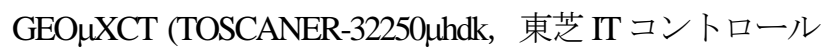
システム製)をを写真-1 に示す. 最大管電圧は $225 \mathrm{kV}$, 最 大管電流は $888 \mu \mathrm{A}$, 最小焦点サイズは $4 \mu \mathrm{m}$ であり, 最 
表-1 X 線CT装置およびFPD の仕様

\begin{tabular}{c|cc}
\hline \multirow{4}{*}{ X 線源 } & 最大管電圧 $[\mathrm{kV}]$ & 225 \\
& 最大管電流 $[\mu \mathrm{A}]$ & 888 \\
& 最大消費電力 $[\mathrm{W}]$ & 200 \\
& 最小焦点サイズ $[\mu \mathrm{m}]$ & 4 \\
\hline \multirow{5}{*}{ Flat Panel } & マトリクスサイズ $[\mathrm{Voxel}]$ & $1024^{2}$ \\
Detector (FPD) & 最大空間分解能 $[\mu \mathrm{m}]$ & 5 \\
& 積分時間 $[\mathrm{ms}]$ & $66-999$ \\
& ビュー数 & $600-4800$ \\
& 積算枚数 & $10-50$ \\
\hline
\end{tabular}

大 $5 \mu \mathrm{m}$ の空間分解能で物体を可視化する. 消費エネル ギー200 W 以内で管電圧と管電流を調節し，被検体の大 きさに応じて最適な撮影条件を設定する．X線ワークテ 一ブルは上下左右への移動が可能であり，X 線管にワー クテーブルを近づけるほど大きな拡大率を得ることがで きる．撮影中はワークテーブルが 360 度回転することで 様々な角度から X 線投影画像を撮影し，画像演算を用 いて断面画像を再構成する. これらの連続した断面画像 を重㸚合わせることで，三次元の CT 画像が得られる.

断面画像は, X 線減衰係数の空間分布に基づいて再構 成される. X 線減衰係数は, 物質の密度, 原子組成およ びX線エネルギーに依存し，その空間分布は CT 值に換 算される. 地盤材料を CT 撮影寸る場合, CT 值は物質 の密度とほぼ線形関係にあることが経験的に知られてい る ${ }^{11}$. CT 画像は Voxel (ボクセル)と呼ばれる画素で構成 され，各々の Voxel 内に含まれる物質の平均密度に対応 する CT值が 16 ビットの範囲で格納される.

検出器には Flat Panel Detector (FPD)を用いており, 従来 型の X 線検出器に比べて信号劣化を抑え, 高解像度の CT 画像が取得できる.X X 線 CT 装置および FPD の仕様 を表-1 に示寸．ここで，表中のビュー数は，ワークテ ーブルが 360 度回転する間に投影する方向数を決める值 である．また，表中の積算枚数は，一度の投影において 収集するデータ数であり, データを加算平均することで ノイズを抑制する。

供試体は，X 線が透過可能な無色透明の円筒型アクリ ルセル内に設置し，ワークテーブル上に固定することで, 三軸圧縮試験中に X線 CT 撮影を並行して実施できる. 試験中, 拘束圧として空気圧 $50 \mathrm{kPa}$ を与え, 排気一排水 条件で実施した，試験中，供試体下部は二重管ビュレッ 卜の水につないで排水平衡時の水頭差 $10 \mathrm{~cm}$ を保ち, 供 試体上部は湿度 $99 \%$ 以上の大気圧に解放し乾燥を防い だ. せん断するとダイレイタンシーでビュレットの水位 が変動するため, ビュレットの高さを調整し水頭差を維 持した．排水量は，二重管ビュレットに搭載した差圧計 で計測した。供試体が軸ひずみ $21 \%$ \%至るまで，ひず み速度 $0.10 \% / \min の$ 変位制御で載荷した.

本研究では，軸ひずみ $0 \% ， 2 \% ， 4 \% ， 6 \% ， 9 \%$,
表-2 X線CT撮影の条件

\begin{tabular}{ccc}
\hline 撮影種類 & Global tomography & Local tomography \\
\hline 管電圧 $[\mathrm{kV}]$ & 160 & 160 \\
管電流 $[\mu \mathrm{A}]$ & 250 & 100 \\
Voxel サイズ $[\mu \mathrm{m}]$ & $72.6 \times 72.6 \times 80.0$ & $12.3 \times 12.3 \times 14.0$ \\
撮影直径 $[\mathrm{mm}]$ & 74.4 & 12.3 \\
撮影高さ $[\mathrm{mm}]$ & 72.8 & 12.3 \\
積分時間 $[\mathrm{ms}]$ & 133 & 133 \\
ビュー数 & 2253 & 4506 \\
積算枚数 & 5 & 10 \\
\hline
\end{tabular}

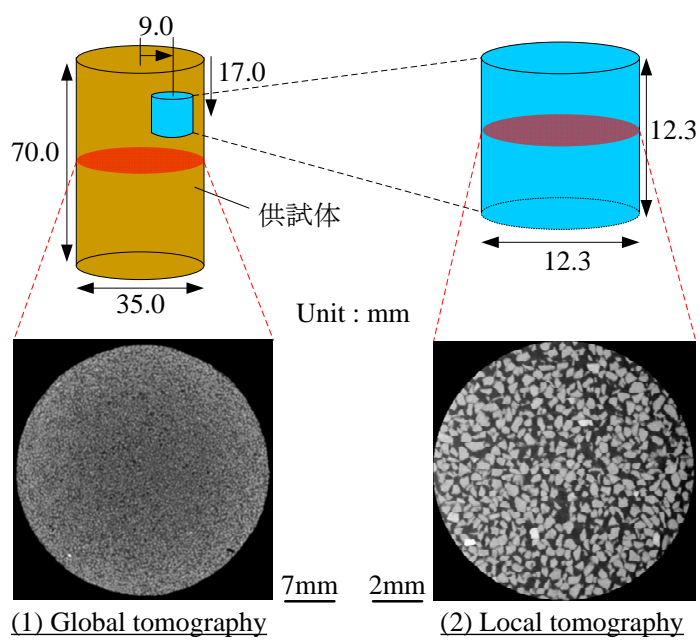

図-3 X 線 CT撮影の種類

$12 \%, 15 \%, 18 \%, 21 \%$ 影を実施した (図-3). 1 つ目は，供試体全体の変形・破 壊形態の可視化を目的とし, 解像度を抑える代わりに広 範囲を撮影するものである (Global tomography). 2つ目は, せん断帯が発生・発達すると推測される局所領域を, 個々の土粒子や水が識別可能な高解像度で撮影寸るもの である (Local tomography). Local tomography の撮影位置に ついては，せん断帯が供試体上部の試料キャップの端か ら 45 度程度の角度で生じると推測し, 図-3 のように供 試体直径の中心加横に $9 \mathrm{~mm}$, 供試体上端から下に 17 $\mathrm{mm}$ ずらした位置を，軸ひずみ $0 \%$ での撮影位置とした。 この撮影位置は載荷によって下方向に動くため, 載荷後 に軸ひず夕に応じて撮影位置を調整し，試験終了まで同 じ領域を可視化した，撮影中は供試体が動かないよう， 載荷を一時的に中断した. 2 種類の撮影は合計 3 時間を 要し，撮影後に同じひずみ速度で再載荷した，それぞれ の撮影条件を表-2に示す.

\section{CT 画像解析アルゴリズム}

三軸圧縮過程で取得した Local tomography の CT 画像を 用いて, 三相微視構造の変化を明らかにする. 本研究で 
は，(1) CT 画像を基に土粒子相・水相・空気相の三相を 分割する三值化，(2) 間隙水の存在形態と数を調べる Morphology 解析, (3) せん断変形中のサクション変化を 調べるために間隙水の曲率解析を実施した. 以下，各画 像解析のアルゴリズムについて述べる.

\section{(1) 三值化}

本研究では, 先行研究 16,19)で適用されている Region growing 法によって三值化を行う. Region growing 法とは, 物体を代表する CT 值を持つ Voxel を初期点とし，その Voxelに隣接する Voxel の CT 值が設定した許容值以内に ある場合に同じ連続体と見なす処理を繰り返し, 次々と 領域を拡張していく領域分割手法の一つである. 不飽和 土の CT 画像を Region growing 法で三值化するためには, 各相を抽出するための許容值を決定する必要がある。こ こで，不飽和土の CT 画像では，一つの Voxel に二つ以 上の相が含まれる場合がある．特に，土粒子相・空気相 が一つの Voxel を占めるとき，二相の平均密度が水相の それに近いため，その Voxel が水相と誤認される部分容

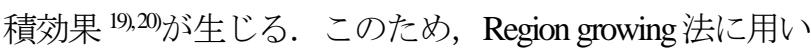
る許容值を決定するにあたり，部分容積効果による Voxel の存在を考慮する必要がある. そこで本研究では, この現象を考慮し，以下に示す手順で Region growing 法 に用いる許容值を決定する ${ }^{17)}$.

1) 土粒子相・水相・空気相の CT 值ヒストグラムが 正規分布に，部分容積効果に起因する三種類の Voxel (土粒子相と水相，水相と空気相，土粒子相 と空気相を占める)の CT 值ヒストグラムが一様 分布関数に従うと仮定する.

2) それら六種類による CT值ヒストグラムを重ね合 わせたものが，元画像の CT 值ヒストグラムと最 も類似した形となるよう，最尤推定法を用いて 決定する.

3) 推定した CT值ヒストグラムにおける土粒子相と 水相のヒストグラムの交点, 水相と空気相のヒ ストグラムの交点より，土粒子相，空気相への Region growing 法に用いる許容值をそれぞれ決定 する. 水相は，土粒子相と空気相の領域分割後 に残った領域とする.

なお, 既知の密度・含水比にある豊浦砂供試体の CT 画像を三值化し, 実験值と解析值が良好な一致を示した. これより，本手法の妥当性を確認している ${ }^{17)}$. 得られる 三值化画像の例を図-4に示す.

\section{(2) Morphology 解析}

三值化画像から水相あるいは空気相のみを抽出し, 個々の連続性を有する水あるいは空気 (以下，クラスタ 一)に分割するクラスターラベリングを実施する．以下,

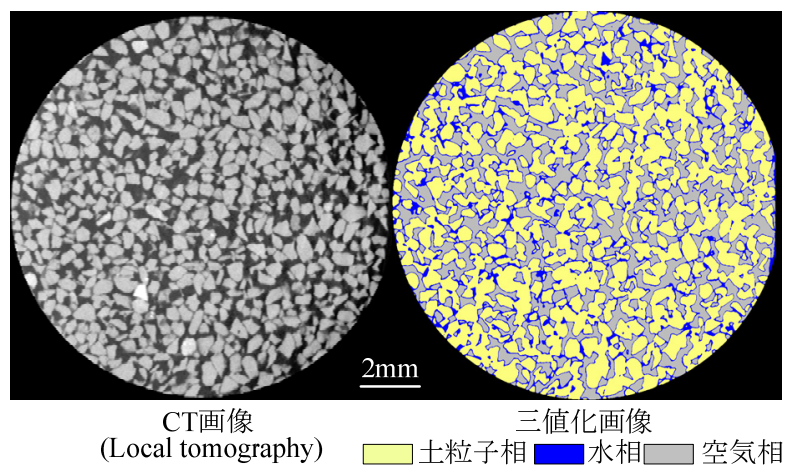

図-4 CT 画像と三值化画像の例(軸ひずみ $0 \%)$

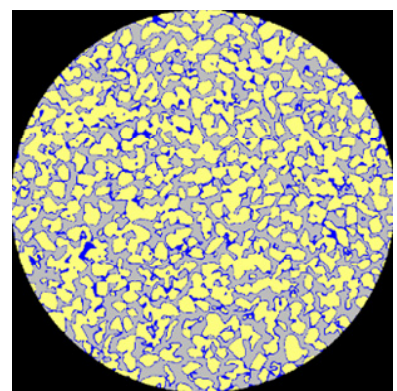

(a) 三值化画像

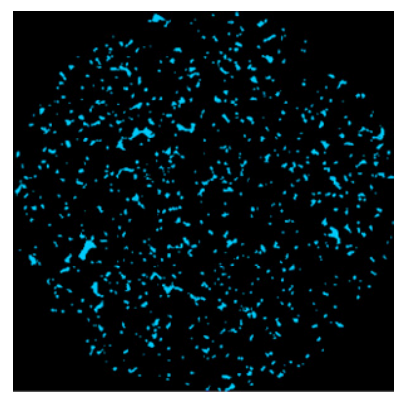

(c) Eroded \& Dilated画像

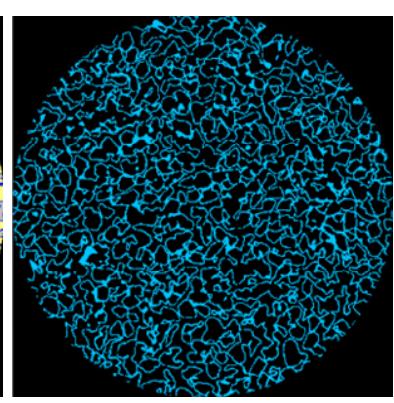

(b) 二值化画像

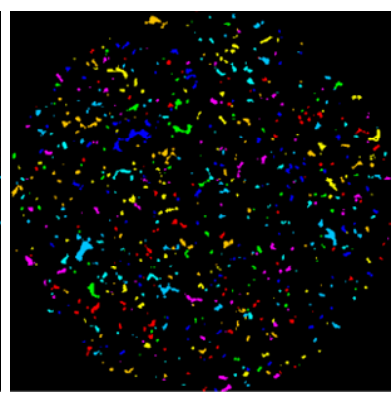

(d) ラベリング画像
図-5 水相を対象とする Mophology 解析の手順

水相を対象とするときの解析手順を示す. なお, 本解析 は三次元画像解析ソフト Avizo9.1.1(FEI)を使用する.

1) 図-5(a), (b)に示すように, 三值化画像から水相を 抽出し, 二值化画像とする。この二值化画像には, 吸着水や，固相と気相の境界に存在する部分容積 効果により水相と誤認された Voxel など，土粒子接 触点周りに存在する間隙水の曲率に寄与しない水 相が含まれる。

2) これらの水相を除去するために Erosion, Dilation の 順に画像処理 21)を行う. Erosion とは, 画像中に存 在する突起状のノイズを除去する処理である。二 值化画像中のすべての水相の Voxel の近傍 6 Voxel を検索し，一つでも水相以外の Voxelがあれば，着 目した水相の Voxel を水相以外の Voxel に置換する. これとは逆に Dilation とは，ノイズの影響で物体中 にあいた孔や亀裂を埋めるための処理である。二 值化画像におけるすべての水相以外の Voxel の近傍 6 Voxel を検索し，一つでも水相の Voxel があれば, 着目した水相以外の Voxel を水相の Voxel に置換す 
る. 図-5(c)に Erosion および Dilation 後の二值化画像 を示す.

3） 2)で得た画像を基にクラスターラベリングを行う. 図-5(d)に示すように，ラベリング画像の色は， 個々のクラスターを区別する番号を意味する.

4) 3)で得たラベリング画像を基に，クラスターの数 および個々のクラスター体積を定量化する.

本解析では，間隙水と間隙空気の連続性を評価する. 連続性は，個々のクラスター体積の総和に対する最大体 積のクラスターの割合とし，式(1)のように表す.

$$
\text { Continuity }=V_{\max } / V_{\text {total }} \times 100
$$

連続性が 100 \%に近いほど，間隙水および間隙空気は大 きな体積のクラスターが 1 つ存在する状態である．逆に 連続性が低くなると, 小さな体積のクラスターが多数存 在する状態となる.

なお，連続性とは Erosion, Dilation によって吸着水等 の曲率に寄与しない水を除去した状態における水の存在 形態を評価するため, 本研究が定義した指標である. そ のため，実際に水が間隙内で連続した状態かを直接的に 示すものではないことに注意されたい.

\section{(3) 曲率解析}

不飽和土内の間隙水と間隙空気の境界は，水の表面張 力と土粒子の親水性によって湾曲しており, サクション が働く.このとき，理想球を仮定した場合のサクション と間隙水の曲率との間には，たとえば式(2)の簡易式 22)で 表されるような正の相関関係がある.

$$
u_{a}-u_{w}=\frac{T}{r_{1}}-\frac{T}{r_{2}}
$$

ここで， $u_{a}$ は間陌空気圧， $u_{w}$ は間隙水圧， $u_{a}-u_{w}$ はサク ション， $r_{1}$ と $r_{2}$ は水と空気の接触面における主曲率半径, $T$ は水の表面張力で摂氏 $20^{\circ} \mathrm{C}$ とき $0.074 \mathrm{~N} / \mathrm{m}$ である. 不飽和土では式(2)の左辺，つまりサクションが常に正

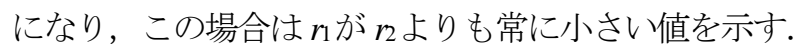

また，図-6 中の土粒子半径 $R$ と水の充填角度 $\theta$ 用い て，r光 $r_{2}$ は以下のように表せる ${ }^{23) .}$

$$
\begin{gathered}
r_{1}=R\left(\frac{1}{\cos \theta}-1\right) \quad r_{2}=R \tan \theta-r_{1} \\
0 \leq \theta<53^{\circ} \quad r_{1}<r_{2}, u_{a}-u_{w}>0 \\
53 \leq \theta \leq 90^{\circ} \quad r_{1} \geq r_{2}, u_{a}-u_{w} \leq 0
\end{gathered}
$$

ここで，本研究で用いた試料の $D_{50} よ り ~ R=230 \mu \mathrm{m}$ と仮 定し，式(2)および式(3)を用いると，図-7 のように $r_{1}, r_{2}$ とサクションの関係が導ける. 図-7 より, 本研究で作 製した不飽和砂供試体に作用する $1.0 \mathrm{kPa}$ のサクション において，r光 $r_{2}$ に比べて 2 オーダー程度小さいことが わかる、また，r而がさくなると $r_{2}$ の影響も含む式(2)で

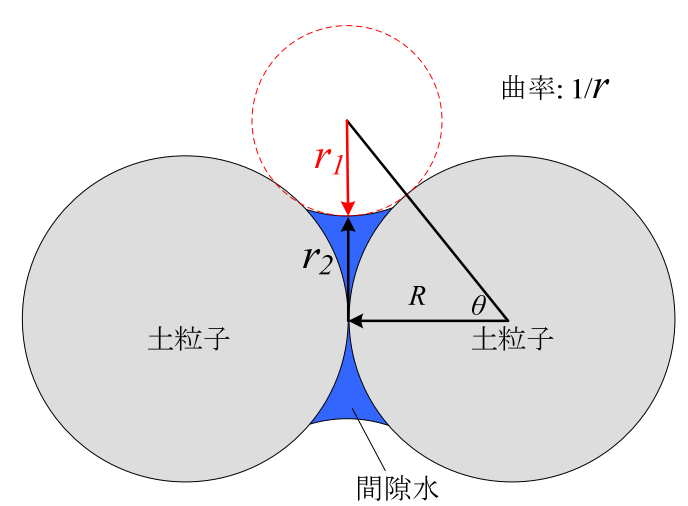

図-6 メニスカス水の曲率半径と曲率

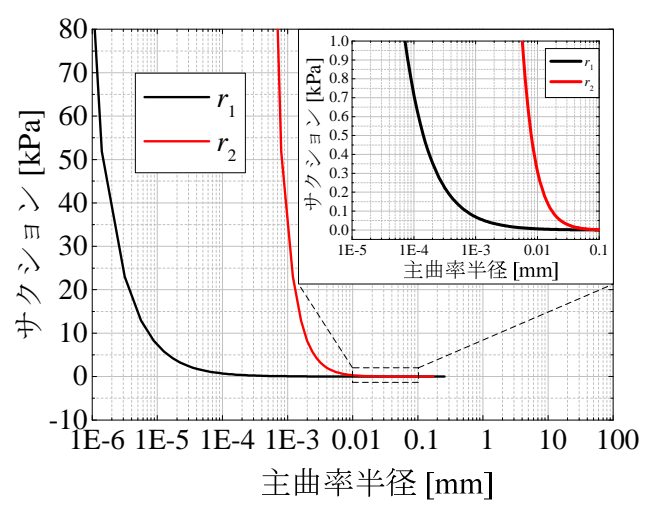

図-7 曲率半径とサクションの関係

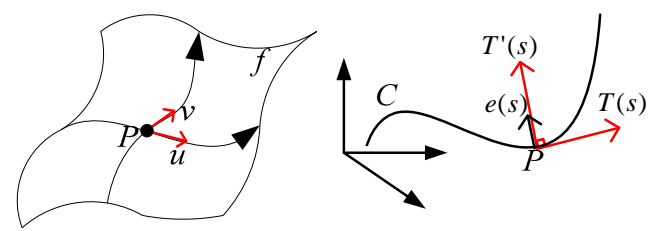

$u, v:$ 接触面の点 $P$ V $T(s):$ 点 $P$ の接ベクトル おける接ベクトル $T^{\prime}(s)$ : 点 $P$ の曲率ベクトル

$e(s)$ : 点 $P$ の単位法線ベクトル

\begin{tabular}{ll} 
(a) 接触面 $f \quad$ (b) 接触面上の点 $P$ を通る曲線 $C$ \\
\hline
\end{tabular}

図-8 接触面上の曲線の曲率ベクトルの概念図

評価されるサクションは単調に増加することがわかる. 以上より，rがサクションに及ぼす影響は小さく， $r_{1}$ の 増減を測定すればサクションの増減を議論することがで きる. そこで本研究では，図-6 に示す間隙水の曲率 $1 / r_{1}$ を画像解析によって算出し, せん断変形中のサクション の変化を議論することとした。

三次元接触面の曲率について述べる. 接触面上の任意 の点における曲率は，一般に，接触面の曲がり具合を表 す第二基本形式から得られる. 接平面をつくる一次独立 な接ベクトル $u, v$ で表現される接触面 $f(u, v)$ 上の点 $P(f$ $(u, v))$ を通る曲線 $C$ は, 弧長変数 $s$ を用いて以下の式(3)の ように表せる(図-8(a), (b)).

$$
u=u(s) \quad v=v(s)
$$

よって，曲線 $C$ は以下のように表せる. 


$$
C: f(u(s), v(s))
$$

曲線 $C$ 上の点 $P$ の接ベクトル $T(s)$ は以下のようになる.

$$
T(s)=\frac{d f}{d s}=f_{u} \frac{d u}{d s}+f_{v} \frac{d v}{d s},|T(s)|=1
$$

ここに, $f_{u}$ および $f_{v}$ は接触面の接平面方向の偏微分であ る. 曲線 $C$ の曲率ベクトル $T^{\prime}(s)$ と同じ向きの単位ベク トルを $e(s)$, 曲率を $\kappa(s)$ とすると, 曲率ベクトル $T^{\prime}(s)$ は 以下のように表せる.

$$
\begin{aligned}
& \kappa(s) e(s)=\frac{d T(s)}{d s}=\frac{d\left(f_{u} \frac{d u}{d s}+f_{v} \frac{d v}{d s}\right)}{d s} \\
& =f_{u u}\left(\frac{d u}{d s}\right)^{2}+2 f_{u v} \frac{d u}{d s} \frac{d v}{d s}+f_{v v}\left(\frac{d v}{d s}\right)^{2} \\
& +f u \frac{d^{2} u}{d s^{2}}+f u \frac{d^{2} v}{d s^{2}}
\end{aligned}
$$

つぎに，曲面の法線ベクトル $n$ の曲率ベクトル $T^{\prime}(s)$ の正射影ベクトルを考える. この正射影べクトルを法曲 率といい，以下のような第二基本形式 II で表せる.

$$
\begin{aligned}
& I I=\kappa(s) e(s) \cdot n=f_{u u} \cdot n \cdot\left(\frac{d u}{d s}\right)^{2}+2 f_{u v} \cdot n \cdot \frac{d u}{d s} \frac{d v}{d s} \\
& +f_{v v} \cdot n \cdot\left(\frac{d v}{d s}\right)^{2}+f u \cdot n \cdot \frac{d^{2} u}{d s^{2}}+f u \cdot n \cdot \frac{d^{2} v}{d s^{2}} \\
& =L\left(\frac{d u}{d s}\right)^{2}+2 M \frac{d u}{d s} \frac{d v}{d s}+N\left(\frac{d v}{d s}\right)^{2} \\
& =\left(\begin{array}{ll}
d u / d s & d v / d s
\end{array}\right)\left(\begin{array}{cc}
L & M \\
M & N
\end{array}\right)\left(\begin{array}{l}
d u / d s \\
d v / d s
\end{array}\right)
\end{aligned}
$$

ここで， $L, M, N$ は，接触面 $f(u, v)$ の接べクトル方向に 関する二階導関数の法線成分である. 式 (7)より, 第二 基本形式 II は $L, M, N$ という接触面固有の值および曲 線 $C$ の接ベクトル $d w / d s, d v / d s$ のみで決まる量である. 式(7)で最終的に得られる行列表示より，L, $M, N$ はへ ッセ行列の二次形式に相当し，多变数関数の微分法によ

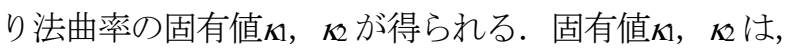
接触面上の任意の点における法曲率の最大值と最小值に 対応する (以下, 主曲率). 本研究では, 主曲率の最大值 凡を間隙水の曲率 $1 / r_{1}$ として計算する。

本研究の曲率解析は, 三次元画像解析ソフト Avizo 9.1.1(FEI)を用いて，以下の手順で実施する.

1) Morphology 解析と同様に, 二值化画像に存在する 吸着水，部分容積効果に起因する水相を除去する ため 1 Voxel $の$ Erosion, Dilation をこの順序で行う.

2) 三值化画像の元々の水相と 1)で得た水相を置換し, 図-9のように水相と空気相の接触面を抽出寸る.

3）図-10 のように，接触面を多数の三角形面に分割す る.このとき，図-11 のように計算対象の三角形を 0 番とすると, その三角形と辺を共有する三角形が
1番, さらにそれらと辺を共有する三角形が 2 番と なり, 最大 20 番まで定義される.

4) 計算対象の三角形面に対し, 最大 20 番までの三角 形面を近傍と見なし，それらの三角形面の最大主 曲率の誤差 (偏差)が最小となるよう, 最小二乗法 に準じて近似解を求める。 つまり，接触面上の任 意の場所にある三角形面の曲率が，その周辺の三 角形面の曲率と等価になるように近似される.

5）接触面を構成するすべての三角形に対して 4)の計 算によって得られた曲率の平均值を計算する.

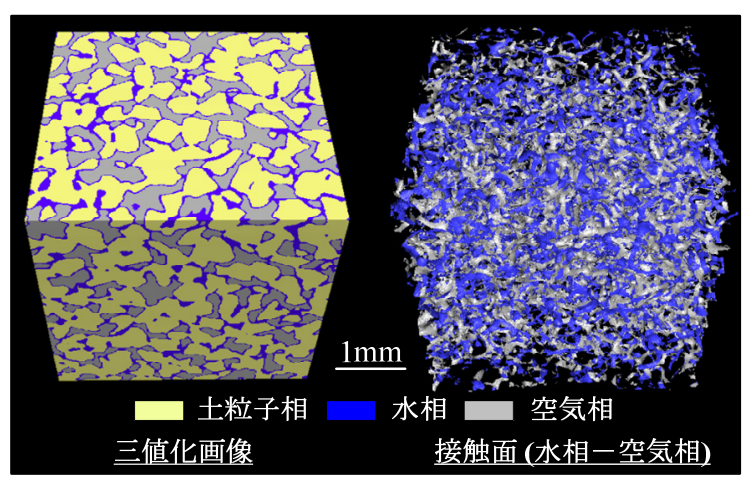

図-9 三值化画像から抽出した水相と空気相の接触面

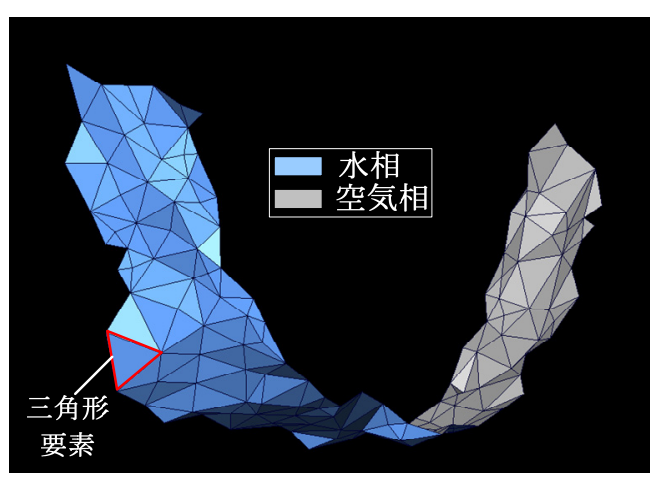

図-10 水相と空気相の接触面を構成する三角形

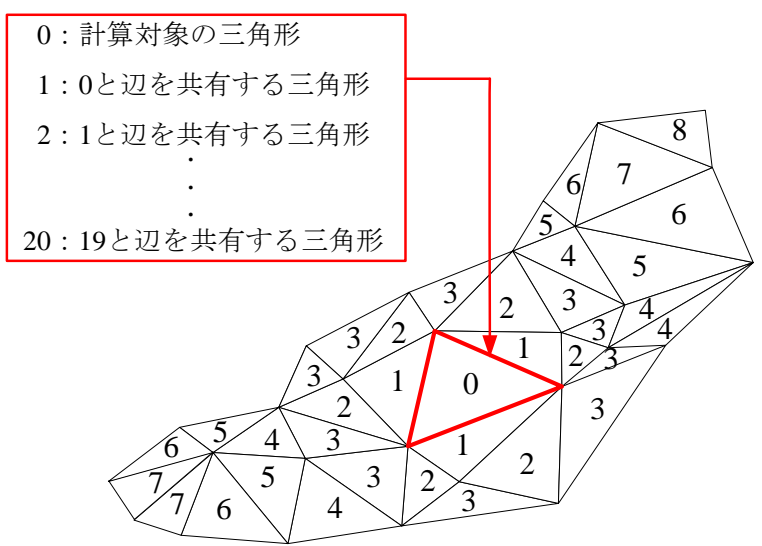

図-11 曲率の計算対象の三角形と近傍の三角形 


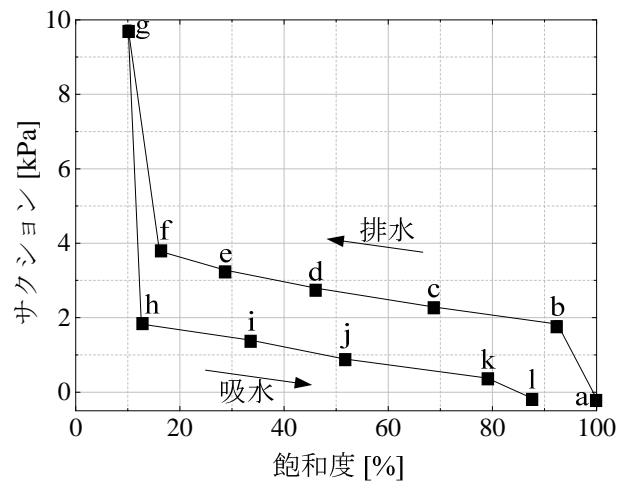

図-12 ゆる詰め豊浦砂の水分特性曲線 24)

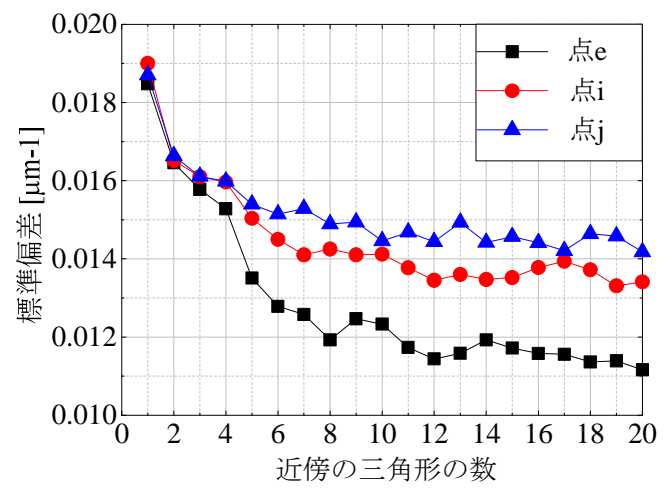

図-13 曲率の標準偏差と近傍の三角形の数との関係

\section{4. 曲率解析の妥当性の検証}

\section{(1) 検証データ}

本解析を実施するに先立ち，曲率計算における三角形 の近傍数の影響と，得られた曲率が間隙水の曲率として 妥当かどうかを検証する必要がある，そこで，ゆる詰め 豊浦砂供試体を用いた水分保持特性試験 ${ }^{24}$ の排水・吸水 過程で取得した三值化画像を用いて曲率解析を行った. ここで，豊浦砂の土粒子密度は $2.64 \mathrm{~g} / \mathrm{cm}^{3}$ ，最大間隙比 は 0.975, 最小間隙比は 0.614, 平均粒径 $\left(D_{50}\right)$ は $185 \mu \mathrm{m}$ で あり, 供試体は直径 $18.0 \mathrm{~mm}$, 高さ $17.7 \mathrm{~mm}$, 間隙比 0.822 (相対密度 $42.1 \%$ ) となるように水中落下法で作製し ている. その後, 飽和度 $100 \%$ 加排水・吸水の順に水 頭型吸引法 ${ }^{18)}$ によってサクションを段階的に与え, 平衡 に至った際に 5.5×5.5×7.0 $\mu \mathrm{m}$ の Voxel サイズでCT撮影を 実施している. 図-12 に水分特性曲線を示寸，なお，図一 12 中の点 $\mathrm{f}, \mathrm{h}$ では CT 画像を取得していないため, 解 析は実施していない.

\section{(2) 近傍数の影響}

図-12 の点 e, i, j の三值化画像を対象に曲率解析を実 施した. なお，水相と空気相の接触面を構成する三角形 の数は, 点 $\mathrm{e}$ が 26994261 個, 点 $\mathrm{i}$ が 30697952 個, 点 $\mathrm{j}$ が 18454572 個であり, 各々の三角形に対して曲率を求めて いる. 近傍数を 1 から 20 まで変え, 各三角形で計算し た間隙水の曲率の標準偏差を図-13 に示す．なお，1つ

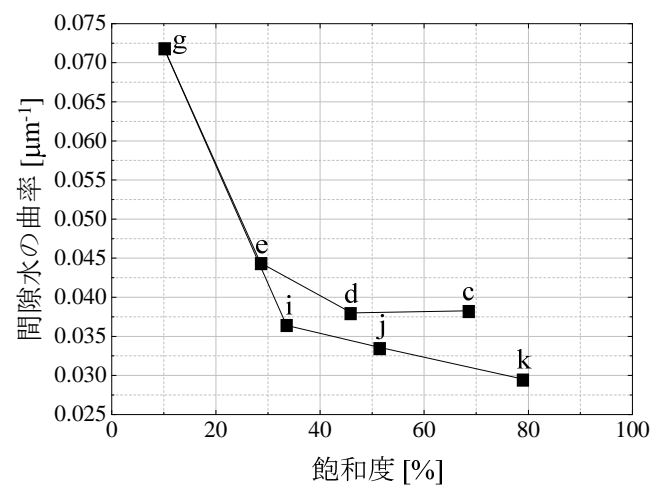

図-14 間隙水の曲率一飽和度関係

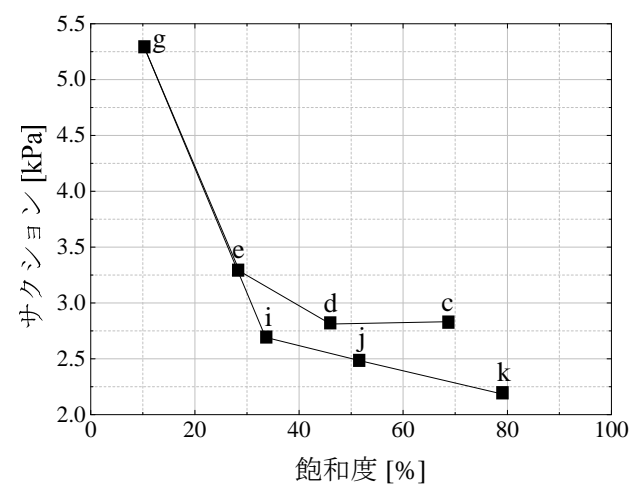

図-15 サクション一飽和度関係

の三角形の面積は $74 \mu \mathrm{m}^{2}$ から $79 \mu \mathrm{m}^{2}$ 程度とほぼ均一の 大きさである. 図-13 より，いずれのケースも近傍数が 多いほど標準偏差は小さくなっている. 特に, 近傍数 6 以上においては，近傍数を変えても標準偏差が増減しな がら収束する傾向が見られる，そこで本研究では，計算 対象の三角形に隣接する 6 番目までの三角形を考慮し, 曲率解析を行った.

\section{（3）間隙水の曲率としての妥当性}

図-12 に示した点のうち，排水過程 (点 c, d, e, g) お よび吸水過程 (点 $i, j, k$ )で取得した三值化画像を用いて 検証する. 具体的には, 各点で得られる曲率一飽和度関 係と図-12 の水分特性曲線を比較し，同様の傾向を示寸 かどうかを確認する。

図-14 に曲率一飽和度関係を示寸. 図-14 の点 c, d, e, $\mathrm{g}$ において飽和度が低下寸るほど曲率が概ね増加してお り，図-12 の排水過程 (点 c, d, e, g)においてサクショ ンが増加する傾向と対応する. また, 図-14 の点 $g, i, j$, $\mathrm{k}$ において飽和度が上昇するほど曲率は減少しており, 図-12 の吸水過程 (点 g, i, j, k)においてサクションが減 少する傾向と対応する. また, 図-14 の点 c, d, e にお ける曲率が，図-14の点 $\mathrm{k}, \mathrm{j}$, i における曲率に比べてそ れぞれ大きな值を示している，これは，図-12 の排水・ 吸水過程に見られるヒステリシスと対応している.これ より, 本研究で提案寸る曲率解析は, 水分保持状態の異 なる間隙水の曲率を相対的に評価する手法として妥当と 
いえる.

つぎに，式(2)を基にサクションの絶対值の推定を試 みた (図-15). 図-12 と比較すると, 飽和度が最も低い点 $\mathrm{g}$ を除いて比較的良く一致した. 点 $\mathrm{g}$ が一致しない理由 については，解像度以下のメニスカスを取得できていな い可能性などが考えられ，今後の課題である.ここで, 先述の通り曲率半径 $r_{2}$ は $r_{1}$ に比べて大きいと考えている ため，図-15は $r_{1}$ のみを考慮した推定值である.

\section{5. 実験結果および解析結果}

\section{(1) 軸差応カー軸ひずみ関係と CT 画像}

図-16 に軸差応力一軸ひずみ関係，体積ひずみ一軸ひ ずみ関係，および画像相関法 14-16)によって求めたせん断 ひずみ場の鉛直断面画像を示す。ここで，せん断ひずみ とは偏差ひずみの第二不変量を指す．また，画像相関法 の解析条件を表-3 に示す。体積ひずみは，三次元可視 化ソフト VGStudioMAX2.2 (Volume Graphics GmbH)を用い て，供試体全体撮影の CT 画像を基に供試体部分の Voxel 数を算出して求めている. なお，図-16に見られる 応力緩和は，およそ 3 時間を要する CT 撮影時に載荷を 中断し，軸ひずみを一定に保っているために生じている. なお，CT 撮影による実験の長期化は供試体の応力履歴 にほとんど影響しないことが確認されている 6 . 図-16 より，軸ひずみ $0 \%$ \%らひずみ硬化し，軸ひずみ 4 \%で $800 \mathrm{kPa}$ 程度のピーク応力を示している. その後, 軸ひ ずみ 21 \%に至るまでひずみ軟化しており，約 $550 \mathrm{kPa} の$ 残留応力を示している. 体積ひずみについては，軸ひず み $2 \%$ 以降に徐々に膨張寸る傾向 (負が膨張)が見られ， 密詰め砂の典型的なダイレイタンシー挙動を示している.

図-17 に Global tomography と Local tomography の CT 画像 を示す. CT 画像は材料の密度の大きさに対応して CT 值が異なり，画像上で白黒の濃淡として現れる．例えば， 金属や砂鉄などの密度が高い物質ほど白く表示され，空 気のように密度が低い物質，あるいは体積変化による密 度低下領域ほど黒く表示される. 図-17 の Global tomography の鉛直断面画像を見ると，軸ひずみ $0 \%$ で既に供試 体中央から上が比較的黒くなっている。 これは供試体作 製において排水させる際，供試体上部ほどサクションが 大きく，供試体上部から比較的多く排水したためと考え られる。軸ひずみが大きくなるにつれて供試体中央部分 に黒い領域が増加しており, せん断によって密度低下し ていることがわかる。 また，軸ずみ 9 \%で斜め方向に 密度低下が見られ，ひずみの局所化が発生していると推 察できる．軸ひずみ 9 \%以降では，この局所化領域が起 点となり明瞭な密度低下領域が発達している.ここで,

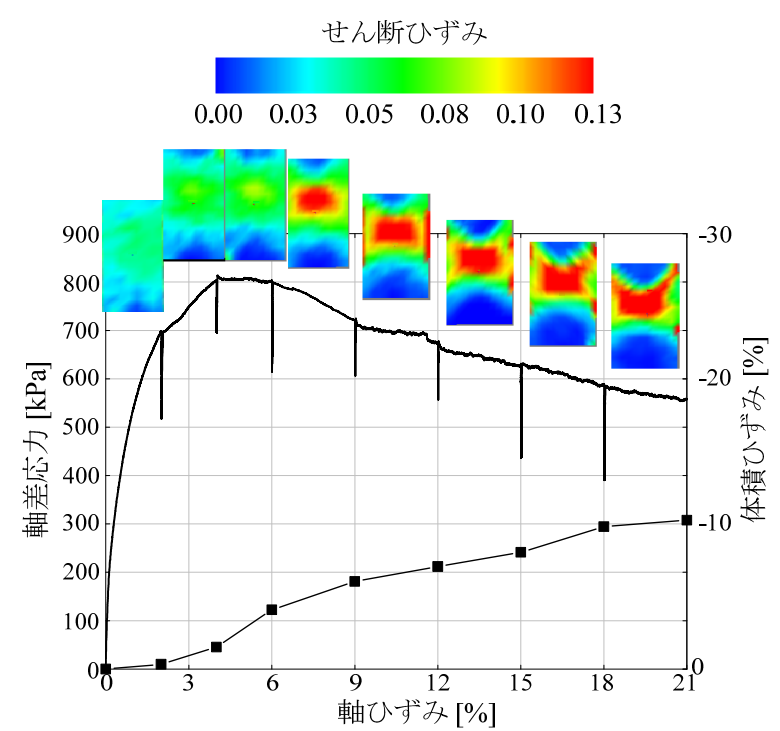

図-16 軸差応力一軸ひずみ関係，体積ひずみ一軸ひずみ関係 およびせん断ひずみ場の鉛直断面画像

表-3 画像相関法の解析条件

\begin{tabular}{cc}
\hline Voxel サイズ $[\mu \mathrm{m}]$ & $72.6 \times 72.6 \times 80.0$ \\
画像寸法 $[$ Voxel] & $650 \times 650 \times 410$ \\
参照点間隔 $[$ Voxel] & 水平方向 : $40 \quad$ 鋁直方向 : 30 \\
計算空サイズ $[$ Voxel] & $21 \times 21 \times 21$ \\
検索空サイズ $[$ Voxel] & $61 \times 61 \times 61$ \\
\hline
\end{tabular}

図-16 のせん断ひずみ場を見ると，はじめは全体的にせ ん断ひずみが発生しているが，局所的に大きなせん断ひ ずみが徐々に卓越する様子が明らかであり，図-17 の斜 め方向に発達する密度低下領域に対応している。 つまり， CT画像に見られる密度低下領域はせん断帯といえる.

図-17 の Global tomographyにおいて，軸ひずみ 12 \%以 降の水平断面画像より，供試体上部では輪のような形状 の密度低下領域が生じている。.また，鈆直断面画像から は斜め二方向から密度低下領域が交差していることがわ かる.これらより，三次元的にはコーン状のせん断帯が 発達したと推測でき, 先行研究 6) 11)の知見と一致する. 供試体中央部分では全体的に密度低下が生じている一方 で，供試体下部ではほとんど変形が見られない.

図-17, 図-18 に示す Local tomography は，撮影中心と 供試体中心をずらして撮影している. そのため，それら の画像の右側が，左側に比べて暗く表示されるアーチフ アクトが生じる．具体的には，偏心により実際の X 線 の透過距離が異なるのに対し，CT 值を用いた画像演算 において透過距離が円形の撮影領域に一律に設定される ため, 供試体中心から遠い箇所の CT 值が相対的に小さ くなる. 本研究の三次元 Local tomography 画像は 878枚の 水平断面画像が鉛直方向に重なって構成されているが, 上記のアーチファクトは鉛直位置の異なる水平断面にお 


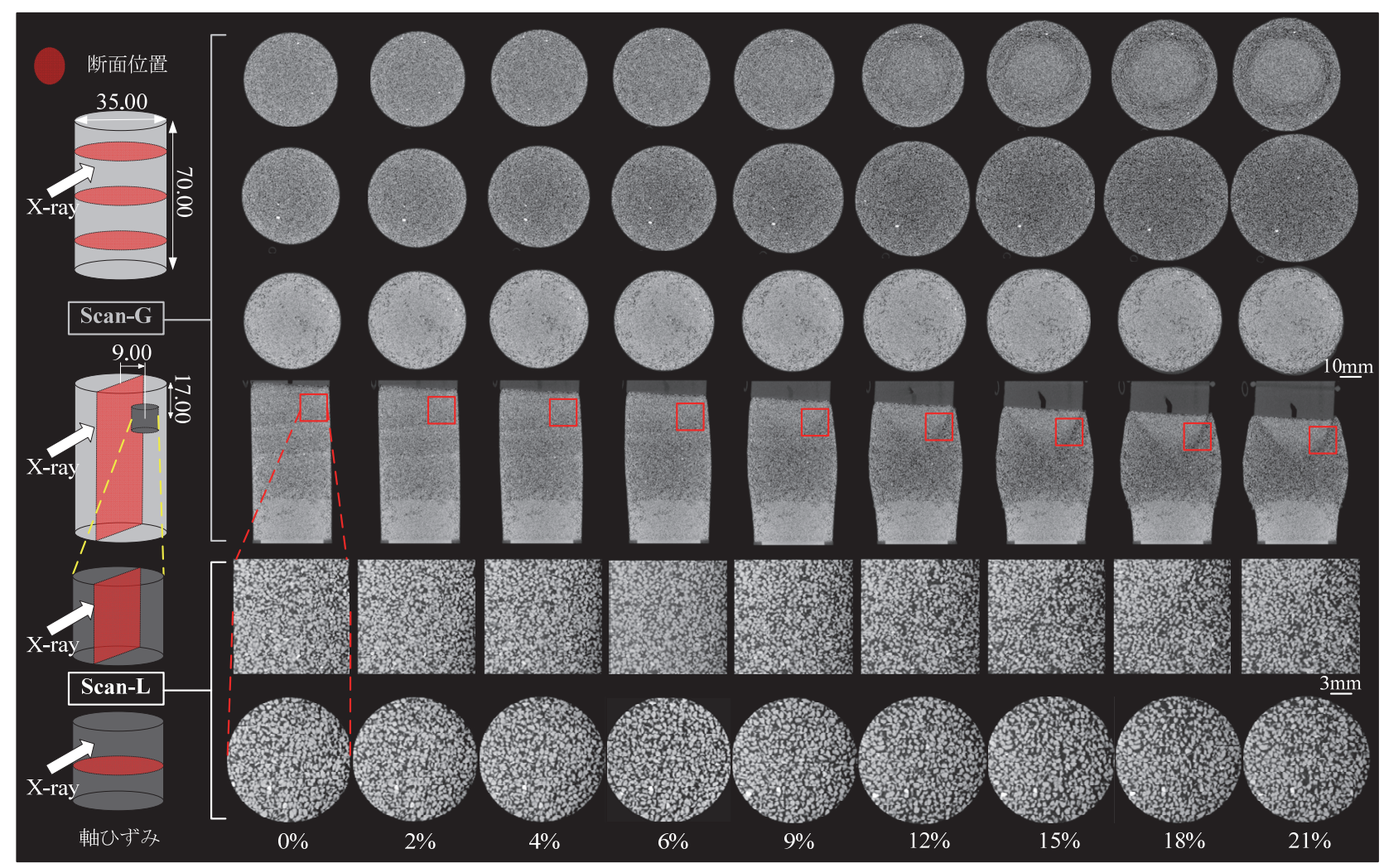

図-17 供試体全体画像(Global tomography)およびせん断帯発生部分の CT 画像(Local tomography)

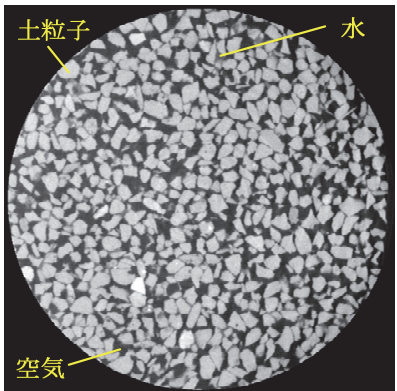

軸ひずみ $0 \%$

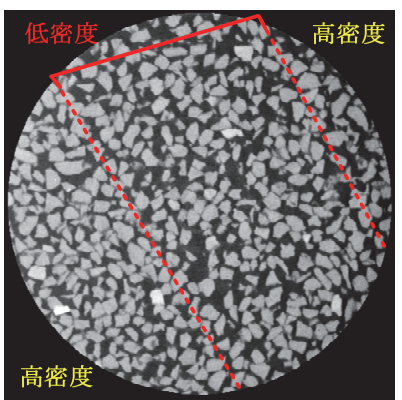

軸ひずタ $21 \%$

(a) 水平断面画像

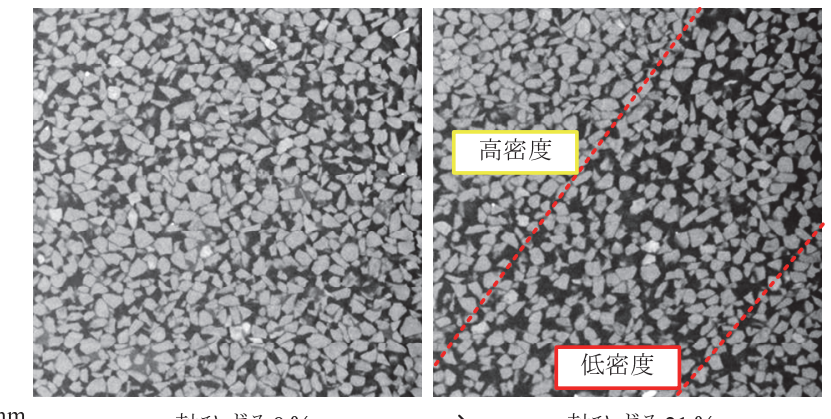

軸ひずみ $0 \%$
軸ひずタ $21 \%$

(b) 鉛直断面画像

図-18＼cjkstart軸ひずみ 0\%および 21\%の Local tomography の CT 画像

いても同様の傾向を示すそそこで本研究では，水平断面 で同じ位置にある 878 個の Voxel の CT 值の平均值から アーチファクトの平面的なトレンドを抽出し，原画像と の差画像を作製する方法でアーチファクトを補正してい る 25)。なお，図-17，図-18 はアーチファクト補正後の CT画像を示している.

図-18における軸ひずみ $0 \%$ ，21\%の Local tomography の CT 画像に見られる白い物質は，珪砂に混在する砂鉄 であり，明るい扊色が土粒子，暗い灰色が水，黒色が空 気である. 初期状態に比べて空気の領域，つまり低密度 領域が局所的に多くなっていることがわかる.

図-18(b)に示すように，ひずみの局所化がより顕著で ある右斜め上方向に発達したせん断帯の幅と角度を計測 した，せん断帯と垂直方向に計 10 か所で計測した幅の
平均值は $5.22 \mathrm{~mm}$ となり，本試料の $D_{50}$ の 11.4 倍となつ た.これは，せん断带の幅が $D_{50}$ の 10 倍程度になるとい う先行研究 6, 12)の知見とほぼ一致する。 また，せん断帯 の角度は約 60 度となった。

\section{(2) せん断帯発達に伴う三相割合の変化}

三值化により，土粒子相・水相 - 空気相の Voxel 数, つまり体積が得られるため，間隙比と飽和度の算出が可 能である. 図-17 の各軸ひずみにおける，アーチファク 卜補正後の Local tomography 全体の CT 画像を三值化して 得られた間隙比一軸ひずみ関係を図-19(a)に，飽和度一 軸ひずみ関係を図-19(b)に示す。ここで，軸ひずみ $21 \%$ の CT 画像は，X 線装置の潜在的なゆらぎに依存して, 解像度が他の画像よりも低かったため, 画像解析の結果 


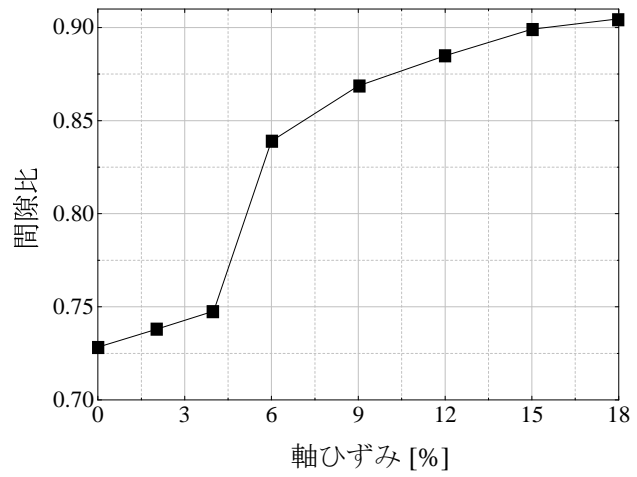

(a)

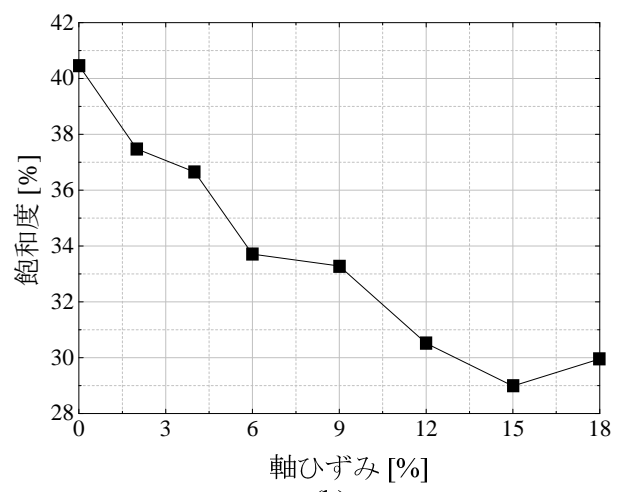

(b)

図-19 Local tomography の CT 画像全体の三值化結果 : (a) 間隙比一軸ひずみ関係(b)飽和度一軸ひずみ関係

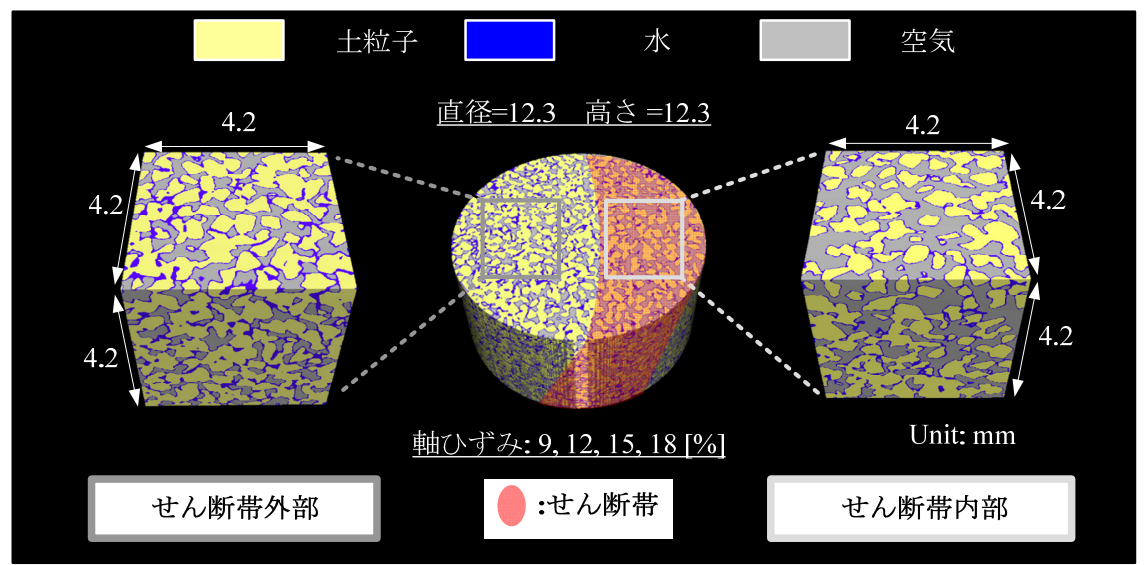

図-20 Local tomography の三值化画像から抽出したせん断帯内外部の三值化画像

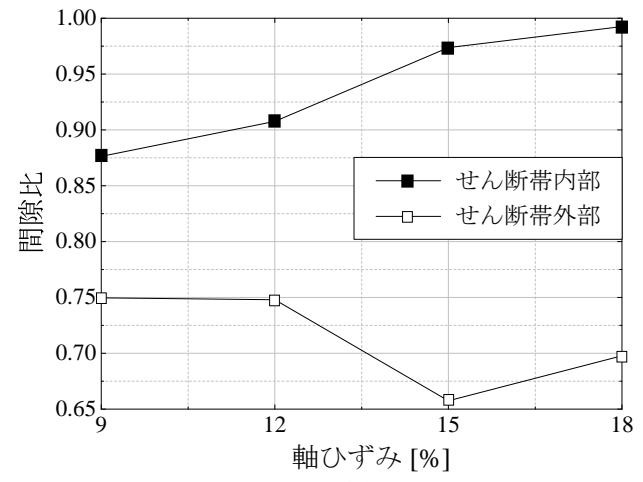

(a)

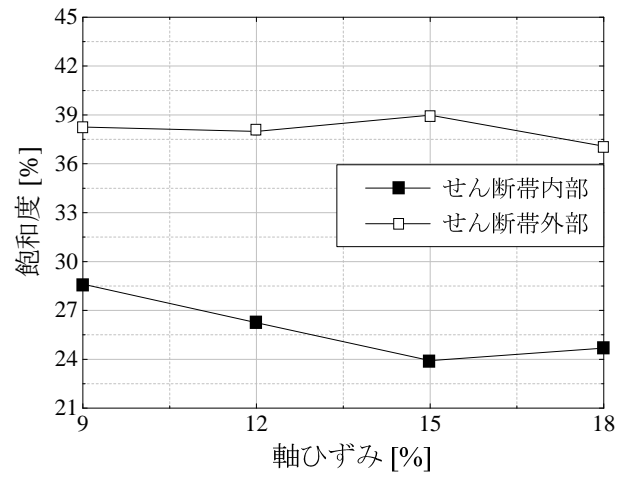

(b)

図-21 せん断帯内外部の三值化結果 : (a) 間隙比一軸ひずみ関係(b)飽和度一軸ひずみ関係

から除外した．図-19(a)より，軸ひずみ 4 \%から間隙比 は一貫して増加しているが，図-19(b)を見ると飽和度は 徐々に低下寸る傾向が見られる。 つまり, 密度低下に伴 い保水性の低下が起こっているのである.

つぎに，図-20 のように Local tomography の三值化画像 から，せん断帯内部とせん断帯外部を抽出し，それぞれ の三相割合を比較する. せん断帯内部は, 図-17 の CT 画像において黒く表示される密度低下領域のみを含むよ うに抽出した。 せん断帯内外部の間隙比一軸ひずみ関係 を図-21(a)に，飽和度一軸ひずみ関係を図-21(b)に示す。 解析を行った軸ひずみ $9 \%$ から $18 \%$ \%かけて，せん断帯
内部における間隙比はせん断帯外部に比べて大きく，か つ飽和度は低い值を示している。

ここで，せん断帯内部の飽和度の低下に対して初期状 態の飽和度分布が影響を及ぼし得るかを検証する，具体 的には，せん断帯内部と同じ大きさの領域 (一辺 $4.2 \mathrm{~mm}$ の立方体)を軸ひずみ $0 \%$ の值化画像から等間隔で 次々と抽出し, 飽和度のヒストグラムを作成する. 先行 研究 ${ }^{24)}$ と同じ手法により，水平・鉛直方向に 50 Voxel 間 隔で抽出を繰り返し，合計 1000 点での飽和度を求めて いる. 図-22 に, 初期状態の飽和度のヒストグラムと, 軸ひずみ $9 \%$ \%ら $18 \%$ までのせん断帯内外部における飽 


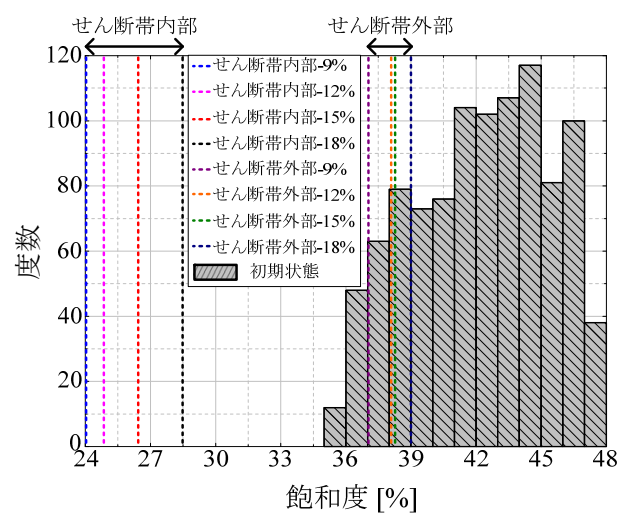

図-22 初期状態とせん断帯内外部での飽和度の比較

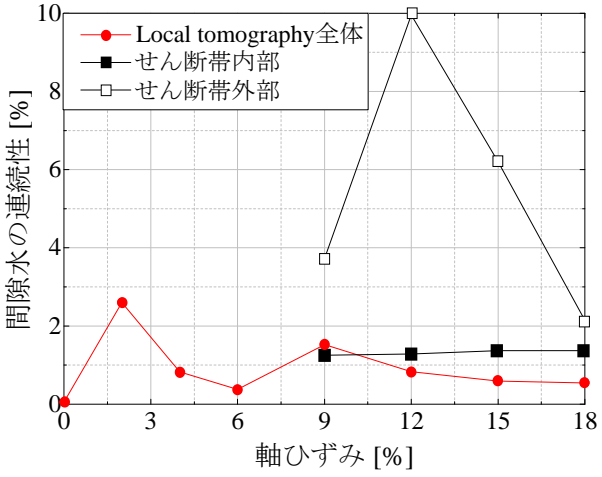

図-23 間隙水の連続性一軸ひずみ関係

表-4 各軸ひずみにおける Local tomography 全体の間隙水クラスターの最大体積および総体積

\begin{tabular}{ccccccccc}
\hline 軸ひずみ $[\%]$ & 0 & 2 & 4 & 6 & 9 & 12 & 15 & 18 \\
最大体積 $\left[\mathrm{mm}^{3}\right]$ & 4.68 & 2.02 & 0.50 & 0.21 & 1.04 & 0.45 & 0.25 & 0.23 \\
総体積 $\left[\mathrm{mm}^{3}\right]$ & 90.61 & 77.62 & 61.18 & 57.03 & 68.05 & 53.84 & 41.61 & 42.39 \\
\hline
\end{tabular}

表-5 各軸ひずみにおけるせん断帯内外部の間隙水クラスターの最大体積および総体積

\begin{tabular}{c|cccc|cccc}
\hline & \multicolumn{4}{|c|}{ せん断帯内部 } & \multicolumn{4}{c}{ せん断帯外部 } \\
\hline 軸ひずタ $[\%]$ & 9 & 12 & 15 & 18 & 9 & 12 & 15 & 18 \\
最大体積 $\left[\mathrm{mm}^{3}\right]$ & $2.36 \times 10^{-2}$ & $2.31 \times 10^{-2}$ & $1.69 \times 10^{-2}$ & $1.74 \times 10^{-2}$ & 0.14 & 0.42 & 0.23 & 0.71 \\
総体積 $\left[\mathrm{mm}^{3}\right]$ & 1.88 & 1.80 & 1.24 & 1.27 & 3.80 & 4.21 & 3.77 & 3.32 \\
\hline
\end{tabular}

和度の比較を示す. 前者は，算出した飽和度の最小值 $35.5 \%$ ，最大值 $47.6 \%$ 範囲内で区間を $3 \%$ として，そ の度数を計上し図-22 の縦軸に示している.これより, 初期状態の飽和度は，軸ひずみ 9 \%以降のせん断帯内部 のそれに比べて十分に高いことが明白である。つまり， せん断帯内部の飽和度の低下は，せん断変形中の密度低 下に起因するのである.

先行研究 26において，限界状態時の密度低下領域では 飽和度が低い状態であると報告されている。これに対し 本研究では，ひずみの局所化の発生から軸ひずみ $18 \%$ までの進展的な密度・飽和度の変化を定量化し，せん断 帯内部は密度低下により一貫して低い保水状態であるこ とを明らかにした。

\section{（3） せん断帯における間隙水の存在形態と数の変化}

図-20 に示す Local tomography およびせん断帯内外部の, 軸ひずみ $18 \%$ \%ま゙の三值化画像を用いて Morphology 解 析を行った．各領域で得られた間隙水の連続性一軸ひず 夕関係を図-23 に示す。また，連続性を求める際に用い た各軸ひずみにおける間隙水クラスターの最大体積, 総 体積について, Local tomography 全体の結果を表-4に，せ ん断帯内外部の結果を表-5 に示す。なお，間隙空気に 対して本解析を行った結果，全ての軸ひず斥において連 続性はほぼ100\%であった。

図-23に示すように，間隙水の連続性は最大でも $10 \%$ 程度と非常に低いことがわかる. 間隙空気の連続性がほ
ぼ 100 \%かつ間隙水の連続性が極めて低いことより，解 析領域における間隙水はメニスカス水として土粒子接触 箇所に存在していると考えられる.また，せん断帯内部 における間隙水の連続性は，せん断帯外部よりも比較的 低くなっている.これより，せん断帯内部では小さな体 積のメニスカス水が存在していると考えられる. なお， 軸ひずみ 2 \%で連続性が一時的に高くなる原因は，せん 断初期で体積変化が小さい場合，せん断によって土粒子 構造が変化する際に間隙水が平衡状態を保てず，流動す ることによって近傍の間隙水が結合するためと推測する.

つぎに，Local tomography 全体およびせん断帯内外部に おける軸ひずみ 18 \%までの間隙水のクラスター数をそ れぞれ図-24, 図-25に示す。連続性に基づく考察から, 解析領域における間隙水はメニスカス水として分布する と考えられるため, 間隙水のクラスター数はメニスカス 水の数と同義といえる. 図-24より，せん断初期ではメ 二スカス水の数が比較的多く，軸ひずみが増加すると数 が減少する傾向にある。これは，せん断により土粒子が 再配列する際にメニスカス水から吸着水へと存在形態が 変化する，あるいは近傍のメニスカス水同士がつながる ためと推察する. 図-25より, 軸ひずみ 18 \%に至るまで, せん断帯内部はせん断帯外部に比べてメニスカス水の数 が少ない状態であることがわかる。これは，せん断帯内 部では密度低下に伴い，土粒子の接触点の数が減少傾向 にあることが原因と考えられる。 


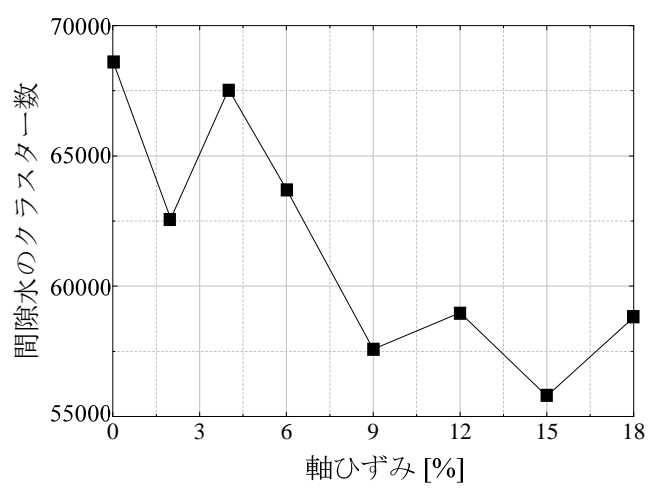

図-24 Local tomography 全体の間隙水のクラスター数

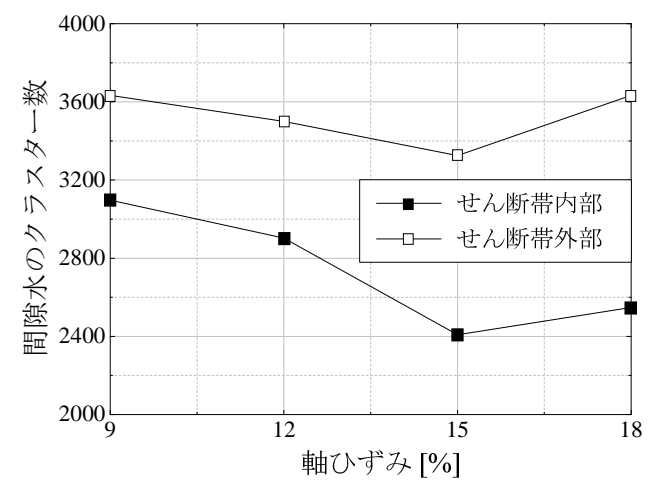

図-25 せん断帯内外部における間隙水のクラスター数

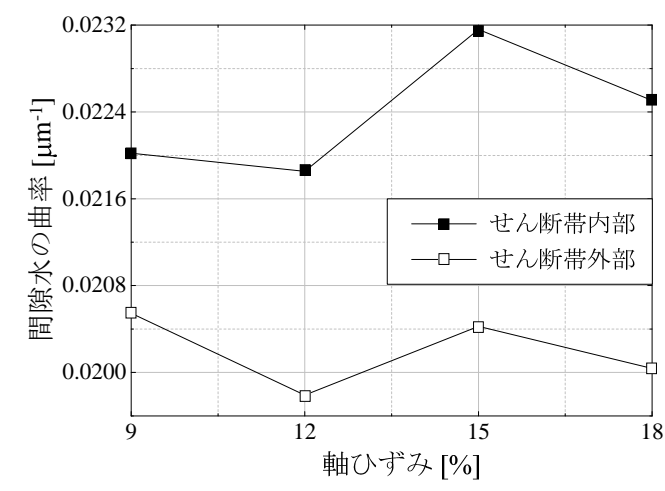

図-26 せん断帯内外部における曲率一軸ひずみ関係

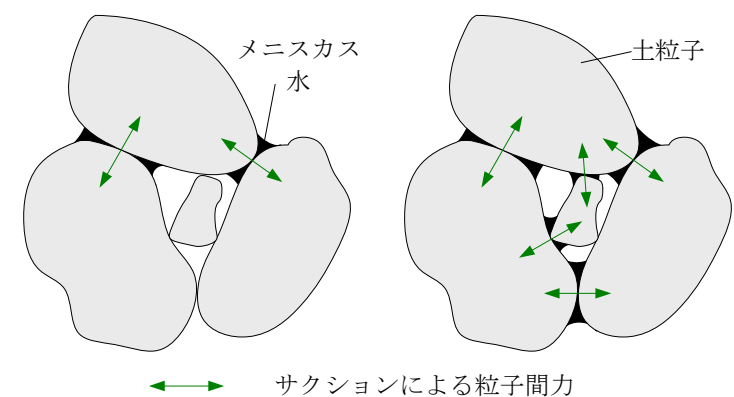

(a) メニスカス水2個 剛性が低い (b) メニスカス水5個 剛性が高い

図-27 メニスカス水の数が岡性へ及ぼす効果の違い

表-6 曲率の平均值, 標準偏差および簡易式 22)から求めたサクション

\begin{tabular}{c|cccc}
\hline & $\begin{array}{c}\text { 曲率の平均值 } \\
\kappa_{\mathrm{ave}}\left(\mu \mathrm{m}^{-1}\right)\end{array}$ & $\begin{array}{c}\text { 曲率の標淮偏差 } \\
\kappa_{\sigma}\left(\mu \mathrm{m}^{-1}\right)\end{array}$ & $\begin{array}{c}\text { サクションの平均值 } \\
S_{\mathrm{ave}}(\mathrm{kPa})\end{array}$ & $\begin{array}{c}\text { サクションの標淮偏差 } \\
S_{\sigma}(\mathrm{kPa})\end{array}$ \\
\hline せん断帯内部 & $2.24 \times 10^{-2}$ & $5.08 \times 10^{4}$ & 1.65 & $3.70 \times 10^{-2}$ \\
せん断帯外部 & $2.02 \times 10^{-2}$ & $3.02 \times 10^{4}$ & 1.50 & $2.23 \times 10^{-2}$ \\
\hline
\end{tabular}

\section{（4） せん断帯における間隙水の曲率}

図-20 に示寸せん断帯内外部の三值化画像を対象に, 解析で得た曲率一軸ひずみ関係を図-26に示す。また, 各軸ひずみでの曲率の平均値と標準偏差を表-6 に示す. 接触面を構成する三角形の面積は第 4 章(2)と同様，およ そ $74 \mu \mathrm{m}^{2}$ から $79 \mu \mathrm{m}^{2}$ 程度とほぼ均一の大きさである.

図-26より，せん断帯内外部それぞれの間隙水の曲率 は，軸ひずみの増加とともに増減している，この増減の 大きさについて, 表-6 の曲率の平均值および標準偏差 を用いて考察する，それぞれを比較すると，曲率の標準 偏差 (せ九断帯内部 : $5.08 \times 10^{4}$, せん断帯外部 : $3.02 \times$ $10^{-4}$ )は各軸ひずみの曲率の平均值 (せん断帯内部 : $2.24 \times$ $10^{-2}$, せん断帯外部 : $\left.2.02 \times 10^{-2}\right)$ に比べて 2 オーダー小さ いことがわかる．これより，軸ひずみの増加に伴う間隙 水の曲率の変化は，せん断帯内外部それぞれの曲率の平 均值に対して十分に小さいといえる. したがって，せん 断により密度・飽和度が変化しても, 間隙水の曲率はほ ぼ一定值を維持するといえる。

参考として，曲率の平均值および標準偏差を基に，式 (2)から推定したサクションを表-6 に示す，なお，本研
究の三軸圧縮試験は排気一排水条件のため，巨視的なサ クションは均一と考えられるが, 曲率から求めたサクシ ヨンはせん断帯内部の方がせん断帯外部に比べて大きく なっている. 両者の差は平衡状態に至っていない場合に 生じる可能性が考えられ，今後の課題である.

\section{（5）軸差応力に寄与する間隙水の微視的特性}

本解析で得た主曲率と, 式(3)の水の充填角度 $\theta$ との対 応関係を調べ，サクションに及ぼす $r_{2}$ の影響を検証する. 表-6より, せん断帯内外部の平均的な曲率 $2.24 \times 10^{-2}$ $\left(\mu \mathrm{m}^{-1}\right), 2.02 \times 10^{-2}\left(\mu \mathrm{m}^{-1}\right)$ を用いると，充填角度 $\theta$ 皇それぞ れ約 33 度, 35 度と求まる。 これは式(3)より， $r_{2}$ が $r_{1} に$ 比べて大きい条件である.また, 図-7 の破線で囲んだ 部分が，それらの曲率に対応する範囲のサクション一曲 率半径の関係であり， $r_{2}$ が $r_{1}$ よりも大きいことが明白で ある．したがって，第3章(3)で述べた通り，主曲率に基 づいてサクションの変化を議論する.

曲率解析により，せん断帯内外部それぞれの領域にお ける間隙水の曲率 $1 / r_{1}$ の変化は, せん断帯が発達する過 程において十分に小さいことがわかった，つまり，不飽 
和土の強度・剛性を高めるサクションのレベルは，せん 断帯の進展によらずほとんど変化しないと考えられる.

つぎに, Morphology 解析で明らかにしたメニスカス水 の数の変化に着目する. 図-24より, せん断初期ではメ 二スカス水の数が比較的多いものの，軸ひずみ $6 \%$ 以降 ではメニスカス水の数が徐々に減少する傾向にあること がわかった. 特に, 図-25 より, せん断帯内部のメニス カス水の数はせん断帯外部に比べて少なく，かつ減少す る傾向を示した. ここで, 図-27 から明らかなように, 同じ土骨格でメニスカス水の数が異なり, 各メニスカス に同等のサクションが作用している状況を考えると, メ 二スカス水の数が多いほど土粒子間力をより強め, 土骨 格の強度・剛性へのサクションの寄与が大きくなる．つ まり，図-24 に見られるように，軸ひずみの増加につれ てメニスカス水の数が減少することは, サクションの強 度・剛性への寄与度が低下していることを意味し, 図16 に見られるひずみ軟化の一因となっていると考えら れる. したがって, 不飽和土の軸差応力はサクションの 大きさだけでなくメニスカス水の数にも依存していると 考えられる.

以上のことから，不飽和砂のひずみ硬化は，メニスカ ス水の数が多く強度・剛性に対するサクションの寄与が 大きいことに起因していると考えられる，一方，ひずみ 軟化は，正のダイレイタンシーによる密度低下すること に加え, メ二スカス水の数が減少し, 強度・剛性に対す るサクションの寄与が消失していくことが一因になって いるのである. 特に, せん断帯内部ではメニスカス水の 数がより少なくなっていることが，ひずみ軟化の重要な 要因の一つになっていると考えられる.

\section{6. 結論}

本研究では，不飽和砂の破壊メカニズムを微視的観点 から解明することを目的とした，そこで，不飽和砂のせ ん断帯の発達過程における三相微視構造の変化を X 線 CT により可視化した. さらに，画像解析によって間隙 水の微視的特性を明らかにし，軸差応力八及ぼす影響を 考察した. 以下, 本研究で得られた結論を列挙する.

1) 軸差応力一軸ひずみ関係は，ひずみ硬化してピー ク応力を示した後, ひずタ軟化する挙動を示した. また，ピーク応力付近でひずみの局所化が生じ, せん断帯を伴う変形・破壊に発展した.

2) せん断帯部分を撮影した画像を三值化した結果, 間隙比が大きく，飽和度が低くなることを明らか にした. 特にせん断帯内部は, せん断帯外部に比 べてこの傾向が顕著である.

3) Morphology 解析を行った結果, 間隙水の連続性が
極めて低く，間隙空気の連続性がほぼ 100 \%である ことを明らかにし，解析データにおける間隙水が メニスカス水として分布すると推察した。 また, メニスカス水の数は, せん断に伴い徐々に減少す る傾向にあり，特にせん断帯内部ではメニスカス 水の数が少ないことを明らかにした。

4) 曲率解析を実施した結果, せん断過程での間隙水 の曲率の変化は十分に小さいことを明らかにした。 これより, 変形前後においてサクションは変化せ ず，ほぼ一定の值を維持すると推察した。

5) ひずみ硬化は，メニスカス水の数が比較的多い状 態で発現している一方で, ひずみ軟化領域では, 軸差応力の低下に伴ってメニスカス水の数が減少 しており，不飽和土の軸差応力はサクションの大 きさだけでなくメニスカスの数にも依存している ことを明らかにした。

6) 正のダイレイタンシーによる密度低下に加えて,

「サクションの大きさが一定であってもメニスカ ス水の数が減少する」という不飽和土に特有の間 隙水の微視的特性が，不飽和土におけるひずみ軟 化の重要な要因の一つになっている.

今後は, せん断に伴い水圧が変化する非排水条件下で 実施した三軸試験データを対象に解析を実施する．その 後, 排水条件のデータと比較することで, 不飽和砂の巨 視的な力学挙動に寄与する微視構造変化の影響をより詳 細に検討していく.

謝辞：本研究は, 京都大学「知の越境」：融合チーム 研究プログラム SPIRITSによる経済的支援を受けた。ま た, 京都大学工学研究科の木村亮教授, Université Grenoble Alpes の Simon Salager 氏，マックスネット(株)の石村貴 暢氏から多くのご支援・ご指導を賜った. ここに記して 謝意を表する.

\section{参考文献}

1) 軽部大蔵, 苗村康造, 森田 登, 岩崎哲雄 : 不飽和土 の力学的性質に関する基礎的研究, 土木学会論文報 告集, No. 269, pp. 105-119, 1978.

2) Alonso, E. E., Gens, A. and Josa, A.: A constitutive model for partially saturated soils, Géotechnique, Vol. 40, No. 3, pp. 405-430, 1990.

3) Kohgo, Y., Nakano, M. and Miyazaki, T.: Verification of the generalized elastoplastic model for unsaturated soils, Soils and Foundations, Vol. 33, No. 4, pp. 64-73, 1993.

4) Fredlund, D. G. and Rahardjo, H.: Soil Mechanics for Unsaturated Soils, John Wiley and Sons, New York, 1993.

5) Cunningham, M. R., Ridley, A. M., Dineen, K. and Burland, J. B.: The mechanical behaviour of a reconstituted unsaturated silty clay, Géotechnique, Vol. 53, No. 2, pp. 183-194, 2003.

6) Higo, Y., Oka, F., Kimoto, S., Sanagawa, T. and Matsu- 
shima, Y.: Study of strain localization and microstructural changes in partially saturated sand during triaxial tests using microfocus X-ray CT, Soils and Foundations, Vol. 51, No. 1, pp. 95-111, 2011.

7) Soulie, F., Cherblanc, F., El Youssoufi, M. S. and Saix, C.: Influence of liquid bridges on the mechanical behaviour of polydisperse granular materials, International Journal for Numerical and Analytical Methods in Geomechanics, Vol. 30, No. 3, pp. 213-228, 2006.

8) 軽部大蔵, 加藤正司, 浜田耕一, 本田道識: 不飽和 土の間隙水の状態と土塊の力学的挙動の関係につい て, 土木学会論文集, No. 535/III-34, pp. 83-92, 1996.

9) Cui, Y. J. and Delage, P.: Yielding and plastic behaviour of an unsaturated compacted silt, Géotechnique, Vol. 46, No. 2, pp. 291-311, 1996.

10) D’Onza, F, Gallipoli, D., Wheeler, S., Casini, F., Vaunat, J., Khalili, N., Laloui, L., Mancuso, C., Mašín, D., Nuth, M., Pereira, J. M. and Vassallo, R.: Benchmark of constitutive models for unsaturated soils, Géotechnique, Vol. 61, No. 4, pp. 283-302, 2011.

11) Desrues, J., Chambon, R., Mokni, M. and Mazerolle, F.: Void ratio evolution inside shear bands in triaxial sand specimens studied by computed tomography, Géotechnique, Vol. 46, No. 3, pp. 539-546, 1996.

12) Oda, M., Takemura, T. and Takahashi, M.: Microstructure in shear band observed by microfocus X-ray computed tomography, Géotechnique, Vol. 54, No. 8, pp. 539542, 2004.

13) Andò, E., Hall, S. A., Viggiani, G., Desrues, J. and Bésuelle, P.: Grain-scale experimental investigation of localised deformation in sand: a discrete particle tracking approach, Acta Geotechnica, Vol. 7, No. 1, pp. 1-13, 2012.

14) Hall, S. A., Bornert, M., Desrues, J., Pannier, Y., Lenoir, N., Viggiani, G. and Bésuelle, P.: Discrete and continuum analysis of localised deformation in sand using X-ray $\mu \mathrm{CT}$ and volumetric digital image correlation, Géotechnique, Vol. 60, No. 5, pp. 315-322, 2010.

15) Takano, D., Lenoir, N., Otani, J. and Hall, S. A.: Localised deformation in a wide-grained sand under triaxial compression revealed by X-ray tomography and digital image correlation, Soils and Foundations, Vol. 55, No. 4, pp. 906-915, 2015.

16) Higo, Y., Oka, F., Sato, T., Matsushima, Y. and Kimoto, S.: Investigation of localized deformation in partially saturated sand under triaxial compression using microfocus X-ray CT with digital image correlation, Soils and Foun- dations, Vol. 53, No. 2, pp. 181-198, 2013.

17) Kido, R. and Higo, Y.: Evaluation of distribution of void ratio and degree of saturation in partially saturated triaxial sand specimen using micro x-ray tomography, International Mini Symposium Chubu, JGS Special Publication, Vol. 5, No. 2, pp. 22-27, 2017.

18) Vanapalli, S. K., Nicotera, M. V. and Sharma, R. S.: Axis Translation and Negative Water Column Techniques for Suction Control, Geotechnical and Geological Engineering, Vol. 26, pp. 645-660, 2008.

19) Higo, Y., Oka, F., Morishita, R., Matsushima, Y. and Yoshida, T.: Trinarization of $\mu \mathrm{X}$-ray images of partially saturated sand at different water-retention states using a region growing method, Nuclear Instruments and Methods in Physics Research B : Beam Interactions with Materials and Atoms, Vol. 324, pp. 63-69, 2014.

20) Hashemi, M. A., Khaddour, G., François, B., Massart, T. J. and Salager, S.: A tomographic imagery segmentation methodology for three phase geomaterials based on simultaneous region growing, Acta Geotechnica, Vol. 9, No. 5, pp. 831-846, 2014.

21) 高木幹雄, 下田陽久 : 新編 画像解析ハンドブック, pp. 866-871, 東京大学出版会, 2004.

22) Lu, N. and Likos, W. J.: Unsaturated Soil Mechanics, John Wiley Sons, Hoboken, NJ, 2004.

23) Dallavalle, J. M.: Micrometrics, Pitman, London, 1943.

24) Higo, Y., Morishita, R., Kido, R., Khaddour, G. and Salager, S.: Local water-retention behavior of sand during drying and wetting process observed by micro x-ray tomography with trinarisation, The 15th Asian Regional Conference on Soil Mechanics and Geotechnical Engineering, JGS Special Publication, Vol. 2, No. 16, pp. 635-638, 2015.

25）肥後陽介, 岡二三生, 木元小百合, 松島祥樹, 吉田 竜也, Hall, S., Viggiani, G.: 三軸圧縮過程における不 飽和砂の三相割合変化の $\mu \mathrm{X}$ 線 CT による定量的評 価, 第 46 回地盤工学研究発表会, No. 6, pp. 15-16, 2011.

26) Higo, Y., Oka, F., Morishita, R. and Matsushima, Y.: Quantitative observation of strain localisation in a partially saturated triaxial specimen using microfocus X-ray CT with image analysis, Proceedings of the 10th International Workshop on Bifurcation and Degradation in Geomaterials, pp. 325-330, 2015.

(2016. 11. 11 受付) 


\section{MICROSCOPIC CHARACTERISTICS OF PORE WATER DURING PROGRESSIVE DEVELOPMENT OF SHEAR BANDS OF PARTIALLY SATURATED SAND UNDER TRIAXIAL COMPRESSION}

\section{Ryunosuke KIDO, Yosuke HIGO and Fukushi TAKAMURA}

It is well known that partially saturated soils show higher strength and stiffness due to suction which works at meniscus water, however, they also exhibit more brittle failure with relatively large strain softening as well as clear shear bands than fully saturated soils and dry soils. It is important to understand the mechanism of brittle failure of partially saturated soils by investigating relation between macroscopic mechanical behavior and three-phase microstructural change such as progressive changes in suction and distribution of meniscus water with development of shear bands. In the present study, shear bands region generated in triaxial compression test of partially saturated sand specimen was observed by x-ray computed tomography. Image analysis provided the curvature, retention states and the number of pore water in order to evaluate the contributions of suction and meniscus water to the deviator stress. It was found that variation in suction due to the development of shear bands is very small. It was also found that relatively large number of meniscus water exists during strain hardening, while the decrease in the number of meniscus water seems to be one of the reason to cause strain softening. It seemed that lower number of meniscus water exists inside shear band so that the contribution to deviator stress is smaller than outside shear bands. 